\title{
Major Elements to Consider in Developing Ammonia Emission Factor at Municipal Solid Waste (MSW) Incinerators
}

\author{
Seongmin Kang ${ }^{1}\left(\mathbb{D}\right.$, Joonyoung Roh $^{2}{ }^{(\mathbb{D}}$ and Eui-chan Jeon ${ }^{2, *}$ \\ 1 Climate Change \& Environment Research Center, Sejong University, Seoul 05006, Korea; \\ smkang9804@gmail.com \\ 2 Department of Climate and Environment, Sejong University, Seoul 05006, Korea; shdod88@naver.com \\ * Correspondence: ecjeon@sejong.ac.kr; Tel.: +82-2-3408-4353
}

Citation: Kang, S.; Roh, J.; Jeon, E.-c. Major Elements to Consider in Developing Ammonia Emission Factor at Municipal Solid Waste (MSW) Incinerators. Sustainability 2021, 13, 2197. https://doi.org/ $10.3390 /$ su13042197

Academic Editor: Silvia Fiore

Received: 20 January 2021

Accepted: 17 February 2021

Published: 18 February 2021

Publisher's Note: MDPI stays neutral with regard to jurisdictional claims in published maps and institutional affiliations.

Copyright: (C) 2021 by the authors Licensee MDPI, Basel, Switzerland. This article is an open access article distributed under the terms and conditions of the Creative Commons Attribution (CC BY) license (https:// creativecommons.org/licenses/by/ $4.0 /)$.
Abstract: $\mathrm{NH}_{3}$ is one of the major substances contributing to the secondary generation of PM2.5; therefore, management is required. In Korea, the management of $\mathrm{NH}_{3}$ is insufficient, and the emission factor used by EPA is the same as the one used when calculating emissions. In particular, waste incineration facilities do not currently calculate $\mathrm{NH}_{3}$ emissions. In the case of combustion facilities, the main ammonia emission source is the De-NOx facility, and, in the case of a power plant with a De-NOx facility, $\mathrm{NH}_{3}$ emission is calculated. Therefore, in the case of a Municipal Solid Waste (MSW) incinerator with the same facility installed, it is necessary to calculate $\mathrm{NH}_{3}$ emissions. In this study, the necessity of developing $\mathrm{NH}_{3}$ emission factors for an MSW incinerator and calculating emission was analyzed. In addition, elements to be considered when developing emission factors were analyzed. The study found that the $\mathrm{NH}_{3}$ emission factors for each MSW incinerator technology were calculated as Stoker $0.010 \mathrm{NH}_{3} \mathrm{~kg}$ /ton and Fluidized Beds $0.004 \mathrm{NH}_{3} \mathrm{~kg} /$ ton, which was greater than the $\mathrm{NH}_{3}$ emission factor $0.003 \mathrm{NH}_{3} \mathrm{~kg}$ /ton for the MSW incinerator presented in EMEP/EEA (2016). As a result, it was able to identify the need for the development of $\mathrm{NH}_{3}$ emission factors in MSW incinerators in Korea. In addition, the statistical analysis of the difference between the incineration technology of MSW and the $\mathrm{NH}_{3}$ emission factor by the De-NOx facility showed a difference in terms of both incineration technology and De-NOx facilities, indicating that they should be considered together when developing the emission factor. In addition to MSW, it is believed that it will be necessary to review the development of emission factors for waste at workplaces and incineration facilities of sewage sludge.

Keywords: PM2.5 secondary sources; municipal solid waste; De-NOx facilities; incinerator type; ammonia emission factor

\section{Introduction}

Ammonia $\left(\mathrm{NH}_{3}\right)$ is a significant contributor to climate change and air pollution. Its negative radiative forcing plays a role in climate change, whereas its contribution to the secondary formation of PM2.5 has emerged as a source of air pollution [1-3]. South Korea is making conscious efforts to reduce the emission of ultrafine particles by managing secondary products, which are one of the major causes of the increase in the concentration of ultrafine particles. In South Korea, NOx (nitrogen oxides) and SOx (sulfur oxides), which are secondary products of ultrafine particles, are being monitored and managed in real-time [4-6]. However, when calculating $\mathrm{NH}_{3}$ emissions, the emission factors suggested by the U.S. Environmental Protection Agency (EPA) and CORINAIR in Europe are used, and there are many unknown sources of omissions [7-9]. Therefore, $\mathrm{NH}_{3}$ emissions do not reflect the characteristics of Korea, and the emission factor values of other countries are used as they are, so the reliability of emissions is low. Systematic management of PM2.5 requires improving the reliability of the inventory's ability to identify emissions, and $\mathrm{NH}_{3}$, one of the secondary generating substances, should improve the reliability of the 
emission inventory by developing emission factors and calculating emissions that reflect the characteristics of the country.

In the case of stationary combustion facilities among the $\mathrm{NH}_{3}$ emission sources dealt with in Korea, selective catalytic reduction (SCR) and selective noncatalytic reduction (SNCR) are used to reduce NOx, an air pollutant. SCR and SNCR are a method of reducing $\mathrm{NOx}$ using $\mathrm{NH}_{3}$. If $\mathrm{NH}_{3}$ is used excessively to reduce $\mathrm{NOx}$, slip may occur, which causes $\mathrm{NH}_{3}$ to be discharged from the final stack [10-13]. Unlike NOx and SOx, which are the main elements emitted by fuel combustion, $\mathrm{NH}_{3}$ reacts using $\mathrm{NH}_{3}$ as a reducing agent to reduce $\mathrm{NOx}$, and the remaining substances are discharged. Therefore, $\mathrm{NH}_{3}$ emission from stationary combustion facilities is characterized by base on the slip, unlike other air pollutants emitted by fuel combustion.

Korea calculates $\mathrm{NH}_{3}$ emissions mainly from boilers used in power generation facilities and businesses among fixed combustion facilities. However, waste incineration facilities are equally equipped with De-NOx facilities to reduce $\mathrm{NOx}$, but $\mathrm{NH}_{3}$ emissions are not calculated when calculating national air pollutant emissions.

Waste incineration facilities use various types of incinerators to dispose of waste, and each type of incineration uses De-NOx facilities to reduce NOx. Combustion efficiency and method may vary depending on the type of incineration. In the case of greenhouse gases $\mathrm{N}_{2} \mathrm{O}$ (nitrous oxide) and $\mathrm{CH}_{4}$ (methane), among the components emitted in relation to combustion, emission factors are developed and divided by waste incinerator type [14]. For NOx, it is determined that incineration types need to be considered to ensure the reliability of the inventory, as they are discharged due to fuel combustion, and the associated $\mathrm{NH}_{3}$ needs to be considered as well. Therefore, in this study, we would like to check whether incineration type should be considered when developing $\mathrm{NH}_{3}$ emission factors.

In addition, in the case of fuel combustion facilities such as power plants, the boiler type is not considered, but emission factors are separately calculated and presented in consideration of SCR and SNCR, which are De-NOx facilities. Therefore, in this study, even when developing the $\mathrm{NH}_{3}$ emission factor for municipal solid waste, we would like to check whether the emission factor for each De-NOx facility should be developed separately. When developing emission factors for incineration type and De-NOx facilities, the elements to consider were evaluated by estimating each $\mathrm{NH}_{3}$ emission factor and analyzing whether there was a statistical difference.

\section{Materials and Methods}

\subsection{Selection of Objective Facilities}

This study was intended to calculate the $\mathrm{NH}_{3}$ emission factor for different incinerator types and De-NOx facilities to identify the need to consider these parameters when developing the $\mathrm{NH}_{3}$ emission factor for MSW incineration facilities. For the $\mathrm{NH}_{3}$ concentration analysis, 515 samples were collected and analyzed. The classification of incinerator types and De-NOx facilities is shown in Table 1. The stoker and fluidized bed combustion type of incinerators were considered and SCR and SNCR were selected for the De-NOx facilities. In South Korea, the stoker type of incinerator is widely used for MSW incineration. Therefore, in this study, the $\mathrm{NH}_{3}$ emission factor was calculated using 476 analysis data from the stoker type incineration facilities. Additionally, the fluidized bed combustion type, which is the second most widely used incinerator type, was selected for comparing the emission factors with those of other incinerator types. To calculate the $\mathrm{NH}_{3}$ emission factor for the fluidized bed combustion type, 39 samples were analyzed.

\section{2. $\mathrm{NH}_{3}$ Concentration Analysis}

The samples were collected according to the process test method proposed by South Korea for $\mathrm{NH}_{3}$ emission concentration measurement, and the indophenol method was selected for sample collection from among the methods proposed in the process test method (odor process test method, air pollution process test method) [15,16]. Indophenol method measures the absorbance of the indophenol reagents that are produced by adding sodium 
hypochlorite solution and phenol or sodium nitroprusside solution into the sample solution. The reagents react with the ammonium ions in the sample solution and the amount of $\mathrm{NH}_{3}$ released is calculated [17]. The $\mathrm{NH}_{3}$ sample was prepared from $\mathrm{NH}_{3}$ absorbent solution (absorbed using $50 \mathrm{~mL}$ boric acid solution), which was taken in two $50 \mathrm{~mL}$ volumetric flasks, and exhaust fumes from $80 \mathrm{~L}$ solution were absorbed for approximately $20 \mathrm{~min}$ at a rate of $4 \mathrm{~L} / \mathrm{min}$ using a pump [18]. $\mathrm{As} \mathrm{NH}_{3}$ dissipates in the presence of moisture, moisture level should be controlled to minimize its effect. Furthermore, high moisture levels occur in exhaust fumes generated by waste combustion; thus, this moisture should also be eliminated prior to $\mathrm{NH}_{3}$ sample collection. Therefore, in this study, a moisture absorption bottle containing silica gel was installed in front of the sample collection apparatus for moisture removal. The $\mathrm{NH}_{3}$ sample was collected based on the schematic diagram shown in Figure 1. The $\mathrm{NH}_{3}$ concentration in the sample solution was estimated by measuring the absorbance of the absorbent solution using the spectrophotometer at a wavelength of $640 \mathrm{~nm}$.

Table 1. Sampling status of objective facilities.

\begin{tabular}{|c|c|c|c|}
\hline Waste Type & Incinerator Type & De-NOx Facilities & Sampling \\
\hline \multirow{6}{*}{$\begin{array}{c}\text { MSW } \\
\text { (Municipal Solid Waste) }\end{array}$} & \multirow{2}{*}{ Stoker } & SCR & 337 \\
\hline & & SNCR & 139 \\
\hline & \multicolumn{2}{|c|}{ Total } & 476 \\
\hline & \multirow{2}{*}{ Fluidized bed } & SCR & 19 \\
\hline & & SNCR & 20 \\
\hline & \multicolumn{2}{|c|}{ Total } & 39 \\
\hline \multicolumn{3}{|c|}{ Total } & 515 \\
\hline
\end{tabular}

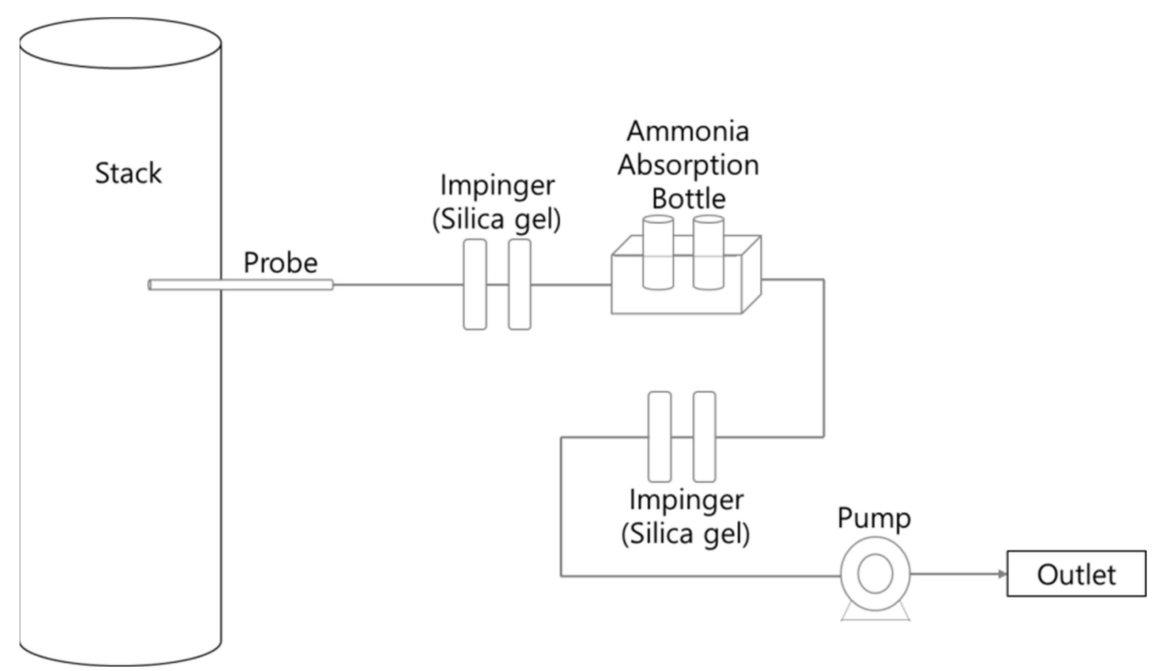

Figure 1. Schematic of the field setup for ammonia sampling at MSW incinerator.

\subsection{Development of the $\mathrm{NH}_{3}$ Emission Factor}

The equation used in the previous studies for calculating the $\mathrm{NH}_{3}$ emission factor was referred to in the present study and the method used has been outlined in Equation (1) $[19,20]$. To estimate the $\mathrm{NH}_{3}$ emission factor of the MSW incineration facility, information on the $\mathrm{NH}_{3}$ concentration, flow rate, and the amount of waste incinerated are necessary. CleanSYS data were acquired from the target workplace and the dailyaccumulated flow rate was used to collect data on the flow rate. CleanSYS is presently being utilized for managing the air pollution in South Korea. CleanSYS measures and man- 
ages the flow rate of $\mathrm{SOx}$, particulate matter (PM), and NOx, and measures the temperature of exhaust fumes and the concentration of air pollutants in real-time. However, it does not measure $\mathrm{NH}_{3}$ at present [21]. The data obtained from the target workplace were used to measure the amount of waste incinerated

$$
E F_{\mathrm{NH}_{3}}=\left[C_{\mathrm{NH}_{3}} \times \frac{M_{w}}{V_{m}} \times Q_{\text {day }} \times 10^{-6}\right] / F C_{\text {day }}
$$

where $E F$ is emission factor ( $\mathrm{kg} \mathrm{NH}$ /ton); $C_{\mathrm{NH}_{3}}$ is $\mathrm{NH}_{3}$ concentration in exhaust gas (ppm); $M_{w}$ is molecular weight of $\mathrm{NH}_{3}$ (constant) $=17.031(\mathrm{~g} / \mathrm{mol}) ; V_{m}$ is one mole ideal gas volume in standardized condition (constant) $=22.4\left(10^{-3} \mathrm{~m}^{3} / \mathrm{mol}\right) ; Q_{\text {day }}$ is daily accumulated flow rate ( $\mathrm{Sm}^{3} /$ day) (based on dry combustion gas); and $F C_{\text {day }}$ is daily waste incineration (ton/day).

\subsection{Statistical Analysis for the Incinerator Types and De-NOx Facilities}

In this study, the average distribution of the $\mathrm{NH}_{3}$ emission factor of different types of pollution prevention facilities and incinerator types of an incineration facility was compared to investigate whether the pollution prevention facility type and incinerator type of an MSW incineration facility affect the $\mathrm{NH}_{3}$ emission factor. SPSS 21 program (IBM, USA) De-NOx was used for statistical analysis; the statistical approach for analyzing the $\mathrm{NH}_{3}$ emission factor difference due to the pollution prevention facility type and incinerator type of an incineration facility is presented in Figure 2.

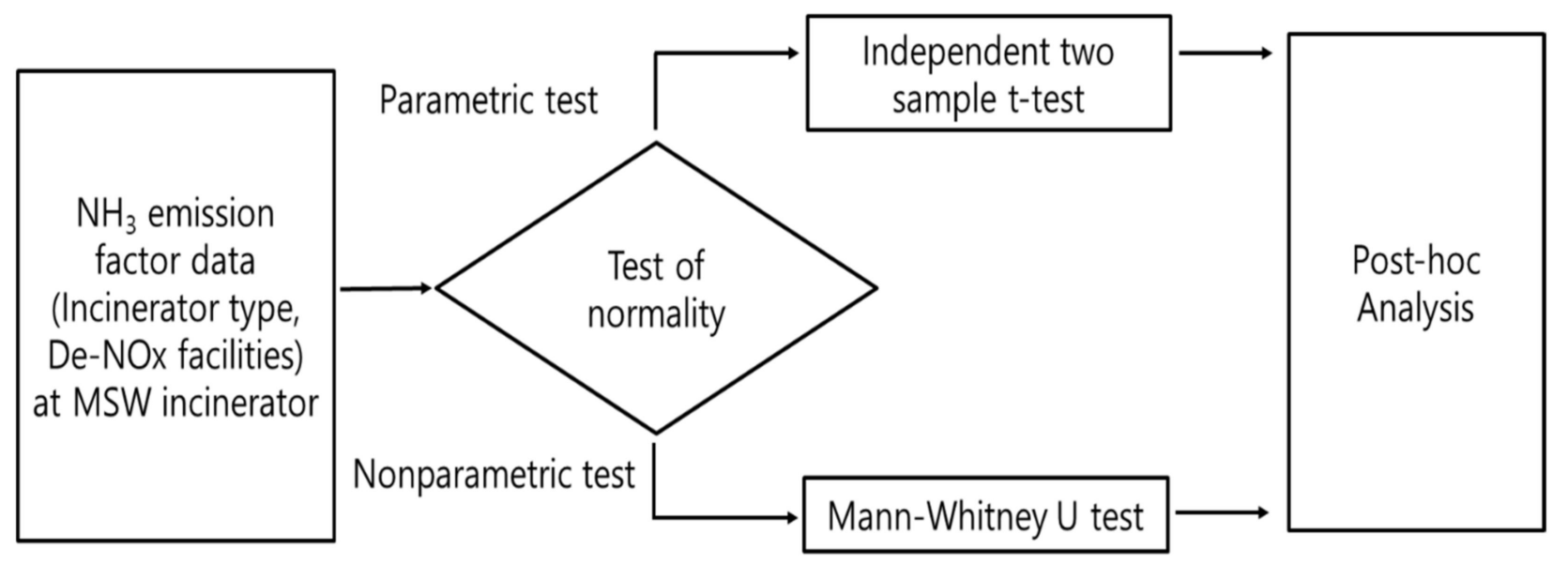

Figure 2. Schematic of statistics analysis.

\section{Results and Discussion}

\section{1. $\mathrm{NH}_{3}$ Emission Factor of the MSW Incineration Facility}

3.1.1. $\mathrm{NH}_{3}$ Emission Factor of Different Incinerator Types of the MSW Incineration Facility

To investigate the elements influencing the $\mathrm{NH}_{3}$ emission factor with respect to different incinerator types, the $\mathrm{NH}_{3}$ emission factor for each incinerator type was calculated, and the results are provided in Table 2. The $\mathrm{NH}_{3}$ emission factor of the stoker type was $0.010 \mathrm{~kg} \mathrm{NH}_{3} /$ ton with a standard deviation of $0.009 \mathrm{kgNH}_{3} /$ ton, while that of the fluidized bed type was $0.004 \mathrm{~kg} \mathrm{NH}_{3} /$ ton, with a standard deviation of $0.004 \mathrm{~kg} \mathrm{NH}_{3} /$ ton. The standard deviation of both stoker and fluidized beds was similar to or greater than the average emission factor. This difference is lower than the $95 \%$ confidence interval of $0.005-0.018 \mathrm{kgNH}_{3}$ / ton of $\mathrm{NH}_{3}$ emission factor for municipal solid waste, suggested by EMEP/EEA (2016), a previous study. Therefore, it was confirmed that the standard deviation of this study was lower than that of previous studies. 
Table 2. $\mathrm{NH}_{3}$ emission factor of MSW incinerator type

\begin{tabular}{|c|c|c|c|c|c|c|}
\hline Waste Type & Incinerator Type & $\begin{array}{l}\text { This Study } \\
\text { ( } \mathrm{NH}_{3} \text { kg/ton) }\end{array}$ & SD & Sampling & $\begin{array}{l}\text { Kang et al. } \\
(2020)[13] \\
\left(\mathrm{NH}_{3} \mathrm{~kg} / \text { ton }\right)\end{array}$ & $\begin{array}{c}\text { EMEP/ } \\
\text { EEA (2016) [8] } \\
\left(\mathrm{NH}_{3} \mathrm{~kg} / \text { ton }\right)\end{array}$ \\
\hline \multirow{2}{*}{ MSW } & Stoker & 0.010 & 0.009 & 476 & 0.009 & \multirow{2}{*}{0.003} \\
\hline & Fluidized bed & 0.004 & 0.004 & 39 & - & \\
\hline
\end{tabular}

In the case of a fluidized bed boiler, the gas temperature is lower than that of the stocker type and the amount of excess air is low, so less NOx is discharged. When less NOx is emitted, the amount of $\mathrm{NH}_{3}$ used to reduce NOx decreases. Therefore, it is judged that the ammonia emission factor is lower in the fluidized bed type than in the stocker type because there is not much $\mathrm{NH}_{3}$ discharged due to slip [22,23].

The results of the $\mathrm{NH}_{3}$ emission factors for MSWs from previous studies were compared with the results of this study. The $\mathrm{NH}_{3}$ emission factor of the stoker type was $0.010 \mathrm{~kg}$ $\mathrm{NH}_{3}$ /ton, which was higher than that $\left(0.009 \mathrm{~kg} \mathrm{NH}_{3} /\right.$ ton) calculated by Kang et al. (2020) and that stated by the European Monitoring and Evaluation Programme (EMEP)/European Environment Agency (EEA) $\left(0.003 \mathrm{kgNH}_{3} /\right.$ ton). In the case of the Stoker incinerator, the difference in $\mathrm{NH}_{3}$ emission factors estimated in the study of Korean facilities was found to be smaller than that of EMEP/EEA in Europe, so it is necessary to develop $\mathrm{NH}_{3}$ emission factors that reflect national characteristics. The $\mathrm{NH}_{3}$ emission factor of the fluidized bed type was $0.004 \mathrm{kgNH}_{3} / \mathrm{ton}$, which was lower than the value acquired by Kang et al. (2020) and higher than that proposed by EMEP/EEA. Therefore, it could be confirmed that, in the case of fluidized-bed incineration, emission factors need to be developed, because they were calculated to be higher than the $\mathrm{NH}_{3}$ emission factors used in Europe.

\subsection{2. $\mathrm{NH}_{3}$ Emission Factor of De-NOx Facilities of the MSW Incineration Facility}

To investigate the effect of the $\mathrm{NH}_{3}$ emission factor with different De-NOx facilities, the $\mathrm{NH}_{3}$ emission factor for each De-NOx facility was calculated; the results are shown in Table 3.

Table 3. $\mathrm{NH}_{3}$ emission factor of De-NOx facilities for MSW incinerator type

\begin{tabular}{|c|c|c|c|c|c|}
\hline Waste Type & Incinerator Type & $\begin{array}{l}\text { De-NOx } \\
\text { Facilities }\end{array}$ & $\begin{array}{c}\text { This Study } \\
\text { ( } \mathrm{NH}_{3} \mathrm{~kg} \text { /ton) }\end{array}$ & SD & Sampling \\
\hline \multirow{4}{*}{ MSW } & \multirow{2}{*}{ Stoker } & SCR & 0.010 & 0.008 & 337 \\
\hline & & SNCR & 0.011 & 0.010 & 139 \\
\hline & \multirow{2}{*}{ Fluidized bed } & SCR & 0.002 & 0.0004 & 19 \\
\hline & & SNCR & 0.006 & 0.0046 & 20 \\
\hline
\end{tabular}

The $\mathrm{NH}_{3}$ emission factor of the SCR facility from among the stoker type of incinerators was $0.010 \mathrm{kgNH}_{3} /$ ton, with a standard deviation of $0.008 \mathrm{~kg} \mathrm{NH}_{3} /$ ton, while that of the SNCR facility was $0.011 \mathrm{~kg} \mathrm{NH}_{3} /$ ton, with a standard deviation of $0.010 \mathrm{~kg} \mathrm{NH}_{3} /$ ton. The $\mathrm{NH}_{3}$ emission factor of the SCR facility with fluidized bed type was $0.002 \mathrm{kgNH}_{3} /$ ton, with a standard deviation of $0.0004 \mathrm{kgNH}_{3} /$ ton, while that of the SNCR facility was $0.006 \mathrm{kgNH}_{3} /$ ton, with a standard deviation of $0.0046 \mathrm{kgNH}_{3} /$ ton, indicating that the $\mathrm{NH}_{3}$ emission factor of the SCR facility was lower than that of the SNCR facility. In the case of the standard deviation of the De-NOx facility, it was found that all the standard deviations of SNCR were larger than that of SCR. This is because SCR has a separate facility and injects ammonia through a nozzle, whereas SNCR is installed in the boiler itself, so it is considered that the deviation is relatively large due to the influence of the environment during the combustion of the boiler [24,25]. The deviation between SCR and SNCR was also found to be lower than the difference between MSW suggested by EMEP/EEA (2016). 
This difference is similar to the difference in $\mathrm{NH}_{3}$ emission factors for each De-NOx facility of a power plant among fixed combustion facilities proposed by EPA. EPA showed that the $\mathrm{NH}_{3}$ emission factor of SCR was higher than that of SNCR [26]. Therefore, it was found that the difference in $\mathrm{NH}_{3}$ emission factor according to the De-NOx facility in this study was significant.

\subsection{Normality Tests for the $\mathrm{NH}_{3}$ Emission Factor of the MSW Incineration Facility}

Prior to analyzing the measured $\mathrm{NH}_{3}$ emission factors statistically, the normality of the data should be examined. Kolmogorov-Smirnov (KS) test, Q-Q plot, chi-square test, and Shapiro-Wilk test are some of the commonly used normality tests. In particular, the Shapiro-Wilk and KS tests are applied based on the size of the population. The KS test is used when the population size is greater than 2000, whereas the Shapiro-Wilk test is used when the population size is less than 2000. These normality tests examine the normality and non-parametric using significance probability. They assume the null hypothesis that the distribution is normal when the significance probability is higher than 0.05 , whereas it switches to non-parametric by rejecting the null hypothesis when the significance probability is lower than 0.05 .

3.2.1. Normality Test for the $\mathrm{NH}_{3}$ Emission Factor for Incinerator Type of the MSW Incineration Facility

To determine whether the incinerator type of the MSW incineration facility should be considered during the $\mathrm{NH}_{3}$ emission factor development, the normality of the $\mathrm{NH}_{3}$ emission factor data for each waste incinerator type was examined using the SPSS 21 statistics program before analysis. As the number of samples for the $\mathrm{NH}_{3}$ emission factor for each waste incinerator type were lower than 2000, Shapiro-Wilk normality test was used. As a result of the review of previous studies, data related to the concentration of gaseous matter emitted from waste incineration facilities in previous studies related to waste and incineration facilities appeared mainly as nonparametric patterns. In the case of the emission factor calculated in this study, it was confirmed that the emission factor was also non-parametric and appeared similar to the previous studies $[27,28]$.

Based on the normality tests, both the Stoker type and fluidized bed type used for the MSW incineration showed a significance probability of less than 0.05 (Table 4). Thus, they were not normally distributed [22,23].

Table 4. The result of normality test $\mathrm{NH}_{3}$ emission factor data of incinerator type at MSW incinerator.

\begin{tabular}{cccc}
\hline \multirow{2}{*}{ Normality Test Result } & \multicolumn{3}{c}{ Shapiro-Wilk } \\
\cline { 2 - 4 } & Statistic & Degree of Freedom, Df & Sig. \\
\hline Stoker & 0.849 & 476 & $<0.001$ \\
\hline Fluidized bed & 0.732 & 39 & $<0.001$ \\
\hline
\end{tabular}

3.2.2. Normality Test for the $\mathrm{NH}_{3}$ Emission Factor of De-NOx Facilities of the MSW Incineration Facility

For the De-NOx waste incineration facilities, the normality of the data of the $\mathrm{NH}_{3}$ emission factor was examined. Since the number of samples for the $\mathrm{NH}_{3}$ emission factor of the De-NOx waste facilities were lower than 2000, Shapiro-Wilk test was used to examine the normality.

Based on the normality test results, the data for the Stoker incinerator type used for MSW incineration showed a significance probability below 0.05 , indicating that the data were not normally distributed (Table 5). Additionally, the significance probability for the data of the fluidized bed type was also lower than 0.05 , confirming that the data were not normally distributed. If the sample size is less than 30 , the number of samples required for the central limit theorem will not be met, even though it is proven to be normally 
distributed through the normality test results, and thus normal distribution cannot be defined and non-parametric tests should be used [29,30].

Table 5. The result of normality test $\mathrm{NH}_{3}$ emission factor data of De-NOx facilities for MSW incinerator type.

\begin{tabular}{ccccc}
\hline \multirow{2}{*}{ Stoker } & & \multicolumn{3}{c}{ Shapiro-Wilk } \\
\cline { 2 - 5 } & & Statistic & Degree of Freedom, Df & Sig. \\
\cline { 2 - 5 } & SCR & 0.862 & 337 & $<0.001$ \\
\hline \multirow{2}{*}{ Fluidized bed } & SNCR & 0.817 & 139 & $<0.001$ \\
\cline { 2 - 5 } & SCR & 0.972 & 19 & 0.808 \\
\hline
\end{tabular}

3.3. Mann-Whitney $U$ Test of $\mathrm{NH}_{3}$ Emission Factor for Incinerator Type and De-NOx Facilities 3.3.1. Mann-Whitney U Test for the $\mathrm{NH}_{3}$ Emission Factor for Incinerator Type of the MSW Incineration Facility

As the $\mathrm{NH}_{3}$ emission factor for different incinerator types of MSW incineration facility did not follow a normal distribution, the comparison between the incinerator types was performed using the Mann-Whitney $U$ test, a non-parametric significance test (Table 6). The Mann-Whitney U test results revealed that the significance probability was less than 0.05 , suggesting that the null hypothesis of " $\mathrm{NH}_{3}$ emission factors for different incinerator types do not show a significant difference" can be rejected. Therefore, the difference in the $\mathrm{NH}_{3}$ emission factors depending on different incinerator types was statistically significant. Hence, the emission factors for each incinerator type need to be developed.

Table 6. The result of Mann-Whitney $\mathrm{U}$ test by $\mathrm{NH}_{3}$ emission factor for MSW incinerator type.

\begin{tabular}{cccc}
\hline Incinerator Type & Mean \pm SD & Z & P-Value \\
\hline Stoker & $0.010 \pm 0.009$ & & -5.763 \\
\hline Fluidized bed & $0.004 \pm 0.004$ & & $<0.001$ \\
\hline
\end{tabular}

3.3.2. Mann-Whitney $\mathrm{U}$ test for the $\mathrm{NH}_{3}$ Emission Factors for De-NOx Facilities of the MSW Incineration Facility

The De-NOx facilities for different incinerator types of the MSW incineration facility did not follow normal distribution based on the normality test results. Therefore, the differences in the $\mathrm{NH}_{3}$ emission factors depending on the different De-NOx facilities were analyzed using the Mann-Whitney $\mathrm{U}$ test; the results are shown in Table 7.

Table 7. The Result of Mann-Whitney U Test by $\mathrm{NH}_{3}$ Emission Factor of De-NOx Facilities for MSW Incinerator Type.

\begin{tabular}{|c|c|c|c|c|}
\hline \multicolumn{2}{|c|}{ Incinerator Type } & Mean \pm SD & $\mathbf{Z}$ & P-Value \\
\hline \multirow{2}{*}{ Stoker } & SCR & $0.010 \pm 0.008$ & \multirow{2}{*}{-1.995} & \multirow{2}{*}{0.046} \\
\hline & SNCR & $0.011 \pm 0.010$ & & \\
\hline \multirow{2}{*}{ Fluidized bed } & SCR & $0.002 \pm 0.0004$ & \multirow{2}{*}{-3.737} & \multirow{2}{*}{$<0.001$} \\
\hline & SNCR & $0.006 \pm 0.0046$ & & \\
\hline
\end{tabular}

The Mann-Whitney $U$ test results show that the significance probability was less than 0.05 , rejecting the null hypothesis, which stated that the $\mathrm{NH}_{3}$ emission factors for different De-NOx facilities for each incinerator type do not show a significant difference. Therefore, the $\mathrm{NH}_{3}$ emission factors depending on the De-NOx facilities for each incinerator type 
of the MSW incineration facility should be considered, and development of the emission factor is necessary.

\section{Conclusions}

$\mathrm{NH}_{3}$ emissions need to be controlled efficiently, as $\mathrm{NH}_{3}$ is a major contributor to climate change and air pollution. However, in South Korea, emission factors abroad are being applied for the calculation of $\mathrm{NH}_{3}$ emissions. In particular, the SCR and SNCR facilities from among the stationary combustion facilities are being utilized in the power plant and workplace combustion facilities, and thus the $\mathrm{NH}_{3}$ emission factor of each fuel needs to be calculated. However, waste incineration facilities use the same facilities but do not calculate $\mathrm{NH}_{3}$ emissions. In the waste sector, only ammonia discharged from the wastewater treatment process is currently calculated as a pollutant source [7]. Therefore, development of the $\mathrm{NH}_{3}$ emission factor for waste incineration facilities is necessary.

In this study, we investigated the necessity of considering the incinerator type and De-NOx facilities while developing the $\mathrm{NH}_{3}$ emission factor for MSW incineration facilities. The $\mathrm{NH}_{3}$ concentration of 515 samples acquired from the MSW incineration facility was analyzed and the subsequent $\mathrm{NH}_{3}$ emission factors for different incinerator types and De-NOx facilities were calculated.

Based on the analysis results, the $\mathrm{NH}_{3}$ emission factor of the SCR facility among the Stoker type was $0.010 \mathrm{kgNH}_{3} /$ ton, with a standard deviation of $0.008 \mathrm{kgNH}_{3} /$ ton, while that of the SNCR facility was $0.011 \mathrm{kgNH}_{3} /$ ton, with a standard deviation of $0.010 \mathrm{kgNH}_{3} /$ ton. In terms of the incineration type, the $\mathrm{NH}_{3}$ emission factor of the SCR facility with the fluidized bed type was $0.002 \mathrm{kgNH}_{3} / \mathrm{ton}$, with a standard deviation of $0.0004 \mathrm{kgNH}_{3} /$ ton, while it was $0.006 \mathrm{kgNH}_{3}$ /ton, with a standard deviation of $0.004 \mathrm{kgNH}_{3} /$ ton of the SNCR facility. This indicated that the $\mathrm{NH}_{3}$ emission factor of the SCR facility was relatively lower than that of the SNCR facility. The comparison of the emission factors of South Korea with that of other countries, the differences in the emission factors estimated for South Korea were smaller than those proposed by other countries. This suggests that there is a need to develop and apply the $\mathrm{NH}_{3}$ emission factor considering the South Korean national standards.

The statistical results for comparison of differences confirmed that the $\mathrm{NH}_{3}$ emission factor of De-NOx facilities for each incinerator type was non-parametric, and hence the Mann-Whitney U test was applied. The result of the statistic, the null hypothesis, which stated that emission factors of each facility were not significantly different, was rejected. Thus, the incinerator type and De-NOx facilities should be considered for the development of the $\mathrm{NH}_{3}$ emission factor.

In this study, the incineration type and $\mathrm{NH}_{3}$ emission factor of De-NOx facilities were calculated for urban solid waste incineration facilities, and the necessity and consideration of the emission factor development were identified, respectively. What could be confirmed by this study and its meaning are as follows:

1. The necessity of developing emission factors reflecting national characteristics was confirmed by suggesting that the difference between the NH3 emission factors calculated in Korea is less than the difference between the $\mathrm{NH}_{3}$ emission factors suggested in Europe;

2. $\mathrm{NH}_{3}$ emission factor according to the incineration type and De-NOx facility of the municipal solid waste incineration facility was presented for reference;

3. In relation to $\mathrm{NH}_{3}$ discharged from municipal solid waste incineration facilities, the need to consider this when developing emission factors was evaluated by statistically analyzing differences according to incineration types and De-NOx facilities. Therefore, if whether other air pollutants also affect the incineration type is checked, the reliability of the inventory can be improved, and a statistical analysis procedure is also presented, so it can be referred to in related studies;

4. In Korea, $\mathrm{NH}_{3}$ emissions are not calculated from waste incineration facilities. In this study, $\mathrm{NH}_{3}$ is also emitted from waste incineration facilities through the research 
results, and the necessity of calculating the emission is also presented by comparing it with overseas emission factors.

In the future, if research calculating the $\mathrm{NH}_{3}$ emission factors for workplace waste and sewage sludge incineration facilities, such as those classified in greenhouse gases other than urban solid waste, is carried out, it is believed that the reliability of the $\mathrm{NH}_{3}$ inventory in the waste sector can be improved. Additionally, emission factors of the pyrolysis melting facility that were not analyzed in this study can be investigated in the future.

Author Contributions: All authors contributed to the research presented in this work. Their contributions are presented below. Conceptualization, E.-c.J.; methodology and writing-original draft preparation, S.K.; analysis, J.R. All authors have read and agreed to the published version of the manuscript.

Funding: This work is supported by Korea Ministry of Environment (MOE) and Korea Environment Corporation.

Institutional Review Board Statement: Not Applicable.

Informed Consent Statement: Not Applicable.

Data Availability Statement: Not Applicable.

Acknowledgments: This work is financially supported by Korea Ministry of Environment (MOE) as Graduate School specialized in Climate Change.

Conflicts of Interest: The authors declare no conflict of interest.

\section{References}

1. Ministry of Environment. Fine Dust, What Is It? Ministry of Environment: Incheon, Korea, 2016.

2. Intergovernmental Panel on Climate Change (IPCC). Fifth Assessment Report_Climate Change 2013; Intergovernmental Panel on Climate Change (IPCC): Geneva, Switzerland, 2013.

3. Ministry of Environment. Management Strategies to Reduce PM-2.5 Emission: Emphasis-Ammonia; Ministry of Environment: Incheon, Korea, 2017.

4. Environmental Preservation Association. POLICY \& ISSUES Environment column: Air Pollutant Total Management System. Environ. Inf. 2015, 416, 2-5.

5. Rhee, V.A. Reveiw of the Special Act on the Seoul Metropolitan Air Improvement: The Total Mass emissions Managements and the Tradable Permit Programs. Public Law J. 2007, 8, 255-280.

6. Moon, T.H.; Hur, J.W. Linking the Total Pollution Load Management System (TPLMS) and the Total Industrial Site Volume Control System (ISVCS) in the Capital Region, Korea. J. Korea Plan. Assoc. 2009, 44, 19-30.

7. NIER (National Institute of Environmental Research in Korea). National Air Pollutant Emission Estimation Manual (III); National Institute of Environmental Research in Korea: Incheon, Korea, 2008.

8. European Environment Agency. EMEP/CORINAIR Atmospheric Emission Inventory Guidebook, 2nd ed.; European Environment Agency: Copenhagen, Denmark, 2016.

9. HSU, Y.; Strait, S.; Roe, S.; Holoman, D. Speciate 4.0: Speciation Database Development Documentation Final Report; U.S. Environmental Protection Agency: Washington, DC, USA, 2007.

10. Seongmin, K.; Seong-Dong, K.; Eui-Chan, J. Emission Characteristics of Ammonia at Bituminous Coal Power Plant. Energies 2020, 13, 1534. [CrossRef]

11. Liu, B.; Yan, F.; Hu, J.; Turkson, R.; Lin, F. Modeling and Multi-Objective Optimization of NOx Conversion Efficiency and NH 3 Slip for a Diesel Engine. Sustainability 2016, 8, 478. [CrossRef]

12. Wielgosinski, G.; Czerwinska, J.; Szymanska, O.; Bujak, J. Simultaneous NOx and Dioxin Removal in the SNCR Process. Sustainability 2020, 12, 5766. [CrossRef]

13. Seongmin, K.; Ji-yun, W.; Eui-Chan, J. Ammonia Emission Characteristics and Emission Factor of Municipal Solid Waste Incineration Plant. Sustainability 2020, 12, 7309. [CrossRef]

14. Intergovernmental Panel on Climate Change (IPCC). 2006 IPCC Guidelines for National Greenhouse Gas Inventories Volume 2 Energy; Intergovernmental Panel on Climate Change (IPCC): Geneva, Switzerland, 2008.

15. Ministry of Environment in Korea. Standard Methods for the Measurements of Air Pollution; Ministry of Environment in Korea: Sejong Si, Korea, 2019.

16. Ministry of Environment in Korea. Standard Method of Odor Compounds; Ministry of Environment in Korea: Sejong Si, Korea, 2019.

17. Asano, Y.; Kaul, P. Hydrolysis and Reverse Hydrolysis: Selective Nitrile Hydrolysis using Nitrilase and its Related Enzymes. Ref. Module Chem. Mol. Sci. Chem. Eng. 2012, 7, 122. 
18. Wujie, W.; Yu, X.; Haochang, S.; Xiaojuan, H.; Keng, Y.; Guoliang, W.; Yucheng, C. Characteristics of Ammonia Removal and Nitrifying Microbial Communities in a Hybrid Biofloc-RAS for Intensive Litopenaeus vannamei Culture: A Pilot-Scale Study. Water 2020, 12, 3000. [CrossRef]

19. Seongmin, K.; Yoon-jung, H.; Seong-Dong, K.; Eui-Chan, J. Ammonia Emission Factors and Uncertainties of Coke Oven Gases in Iron and Steel Industries. Sustainability 2020, 12, 3518. [CrossRef]

20. Seongmin, K.; Yoon-jung, H.; Eui-Chan, J. Ammonia Emission Sources Characteristics and Emission Factor Uncertainty at Liquefied Natural Gas Power Plants. Int. J. Environ. Res. Public Health 2020, 17, 3758. [CrossRef]

21. Daejeon Sejong Research Institute. Management Plan for Particulate Matter Reduction at Autonomous Agreement Air PollutantsReducing Sites; Daejeon Sejong Research Institute: Sejong Si, Korea, 2019.

22. Xin, W.; Guohua, S.; Yizheng, W.; Lei, Y.; Zhiqiang, Z. A NOx Emission Model Incorporating Temperature for Heavy-Duty Diesel Vehicles with Urea-SCR Systems Based on Field Operating Modes. Atmosphere 2019, 10, 337. [CrossRef]

23. María Isabel, L.G.; Laura, C.S.; Carlos, G.R.V. Numerical Analysis of NOx Reduction Using Ammonia Injection and Comparison with Water Injection. J. Mar. Sci. Eng. 2020, 8, 109. [CrossRef]

24. Oliveira, F.C.L.; Martignoni, W.P.; Souza, E.; Pereira, L.G.; Santos, L.S.; Prata, D.M.; Monteiro, L.P.C. Convective Recirculation Effect on The Selective Non-Catalytic Reduction Behavior in an Industrial Furnace. Braz. J. Chem. Eng. 2017, 34, 1011. [CrossRef]

25. Pronobis, M. Environmentally Oriented Modernization of Power Boilers, 1st ed.; Elsevier: Amsterdam, The Netherlands, 2020.

26. U.S. Environmental Protection Agency. Development and Selection of Ammonia Emission Factors Final Report; U.S. Environmental Protection Agency: Washington, DC, USA, 1994.

27. Ruxton, G.; Beauchamp, G. Some Suggestions about Appropriate Use of the Kruskal-Wallis Test. Anim. Behav. 2008, 76, 1083. [CrossRef]

28. Andras, V.; Harold, D.D. The Kruskal-Wallis Test and Stochastic Homogeneity. J. Educ. Behav. Stat. 1998, 23, 170.

29. De Winter, P.; Cahusac, P.M. Starting out in Statistics: An Introduction for Students of Human Health, Disease, and Psychology; John Wiley \& Sons: Hoboken, NJ, USA, 2014.

30. Gibbons, J.D.; Chakraborti, S. Nonparametric Statistical Inference Fourth Edition, Revised and Expanded; Marcel Dekker: New York, NY, USA, 2003. 